LETTERS

\title{
Determination of anti-CCP antibodies in patients with suspected rheumatoid arthritis: does it help to predict the diagnosis before referral to a rheumatologist?
}

\author{
I K Gao, A Haas-Wöhrle, K G Mueller, H-M Lorenz, C Fiehn
}

Ann Rheum Dis 2005;64:1516-1517. doi: 10.1136/ard.2005.035444

$\mathrm{P}$ rognosis in rheumatoid arthritis (RA) depends critically on early diagnosis and timely treatment with immune modulating drugs. As a consequence, early referral and access of patients with suspected RA to rheumatologists is mandatory for the establishment of diagnosis and initiation of treatment.

Measurement of antibodies to cyclic citrullinated peptide (CCP) is a new and highly specific test for the diagnosis of RA. Detection of anti-CCP antibodies-in particular, if the second generation of anti-CCP2 tests is used-has been shown to be of prognostic significance and to be helpful in early diagnosis of RA. ${ }^{1-9}$

The goal of this work was to investigate whether the measurement of anti-CCP antibodies alone or in combination with easily determinable parameters of a patient's complaints and routine laboratory tests might help to identify prospectively patients with a high probability for RA.

For this study 102 patients from a routine rheumatology clinic were examined. All were referred by general practitioners, orthopaedic surgeons, or other non-rheumatological subspecialties because of suspected RA. In all patients the value of the anti-CCP antibody (second generation antiCCP2-test; Euroimmun, Lübeck, Germany), IgM rheumatoid factor (RF, as determined by nephelometry; Beckman Coulter, Krefeld, Germany), C reactive protein (CRP), and erythrocyte sedimentation rate (ESR) were measured, and physical, laboratory, and radiological examinations were performed. RA was diagnosed according to the American College of Rheumatology (ACR) criteria revised in 1987. ${ }^{10}$ All

patients were questioned about the presence of morning stiffness of the joints and or muscles and about the presence of polyarticular pain, which was interpreted as positive if at least four tender joints were reported.

Sensitivity and specificity and-to obtain better information about the diagnostic value with a low pretest probability - the positive and negative predictive values (PPV and NPV) of the tests were calculated. For the latter, the following formulae were used:

$P P V=a /(a+b) ; N P V=d /(c+d)$

where $\mathrm{a}=$ test positive, disease positive; $\mathrm{b}=$ test positive, disease negative; $\mathrm{c}=$ test negative, disease positive; $\mathrm{d}=$ test negative, disease negative.

Moreover, the relative risk of fulfilling the ACR criteria for RA, whether or not the test criteria were present, was determined.

Twenty eight of the 102 patients fulfilled the diagnosis of RA according to the ACR criteria (pretest probability of $27 \%) .{ }^{10}$ The other patients were classified as having unclassified monarthritis, polyarthritis, or oligoarthritis $(n=21)$, arthralgias of unknown origin $(n=20)$, osteoarthritis of the fingers $(n=20)$, psoriatic arthritis $(n=4)$, fibromyalgia $(n=3)$, polymyalgia rheumatica $(n=2)$, cervicobrachialgia $(n=2)$, periostitis $(n=1)$, and reactive arthritis $(n=1)$.

If a patient was positive for anti-CCP, the PPV, or in other words the probability of fulfilling the ACR criteria for RA, increased to $55 \%$ (table 1 ).

This relatively low predictive value of the anti-CCP test was increased when it was combined with easily obtainable

Table 1 Values of the anti-CCP and the rheumatoid factor (RF) test alone or in combination with different laboratory parameters and patient's complaints for the diagnosis of RA

\begin{tabular}{lllllll}
\hline & $\begin{array}{l}\text { Sensitivity } \\
(\%)\end{array}$ & $\begin{array}{l}\text { Specificity } \\
(\%)\end{array}$ & PPV (\%) & NPV (\%) & RR & 95\% Cl \\
\hline Anti-CCP & 43 & 86 & 55 & 80 & 2.7 & 1.5 to 4.9 \\
Anti-CCP plus ESR & 21 & 95 & 60 & 76 & 2.5 & 1.3 to 4.7 \\
Anti-CCP plus RF & 36 & 91 & 59 & 79 & 2.8 & 1.6 to 4.9 \\
Anti-CCP plus CRP & 25 & 97 & 78 & 77 & 3.4 & 2.1 to 5.8 \\
Anti-CCP plus polyarticular pain & 43 & 95 & 78 & 81 & 4.0 & 2.4 to 6.8 \\
Anti-CCP plus morning stiffness & 29 & 99 & 89 & 78 & 4.1 & 2.7 to 6.5 \\
RF & 46 & 78 & 45 & 79 & 2.2 & 1.2 to 4.0 \\
RF plus ESR & 18 & 93 & 50 & 75 & 2.0 & 0.9 to 4.1 \\
RF plus CRP & 18 & 96 & 63 & 76 & 2.6 & 1.3 to 4.9 \\
RF plus polyarticular pain & 46 & 92 & 68 & 82 & 3.8 & 2.2 to 6.6 \\
RF plus morning stiffness & 30 & 97 & 80 & 78 & 3.7 & 2.2 to 6.0 \\
\hline
\end{tabular}

The results of the positive predictive value (PPV) are highlighted. The patient group tested comprised 102 patients with suspected RA who were referred to a rheumatologist. Twenty eight of them fulfilled the ACR criteria for RA (pretest probability of $27 \%$ ).

$\mathrm{PPV}$, positive predictive value; $\mathrm{NPV}$, negative predictive value; $\mathrm{RR}$, relative risk; $95 \% \mathrm{Cl}, 95 \%$ confidence interval for relative risk; anti-CCP, anti-CCP values above normal $(<2 \mathrm{U} / \mathrm{I})$; RF, rheumatoid factor above normal $(<10 \mathrm{U} / \mathrm{I})$; $\mathrm{CRP}, \mathrm{C}$ reactive protein value above normal $(<5 \mathrm{mg} / \mathrm{l}), \mathrm{ESR}$, erythrocyte sedimentation rate $>20 \mathrm{~mm} / 1 \mathrm{st}$; morning stiffness, morning stiffness of at least 60 minutes; polyarticular pain, pain in at least four joints or muscular regions. 
information about the patient's complaints: if a patient had a positive anti-CCP test and at the same time morning stiffness of at least $60 \mathrm{~min}$ the PPV was $89 \%$. In fact, the only patient who was positive for both measures without fulfilling the ACR criteria for RA was thought by the examining rheumatologist to have early RA. Polyarticular pain is a symptom which was present in all patients with RA and, additionally, in the patients with arthralgias, undifferentiated polyarthritis, fibromyalgia and polymyalgia rheumatica. If anti-CCP positive patients had polyarticular pain, a PPV of $78 \%$ and a NPV of $81 \%$ was obtained. In contrast, the combination of anti-CCP and RF, as was suggested by other reports, ${ }^{29}$ did not result in a similar increase of the PPV or NPV (59\% and 79\%, respectively). The rather low sensitivity and specificity of the anti-CCP test (table 1) was in accordance with other reports with similar results obtained in unselected rheumatological patients who were not subjected to a prolonged follow up. ${ }^{11}$

In conclusion, if information about morning stiffness of the joints or polyarticular pain is added, anti-CCP gives us a tool which more accurately predicts the presence of RA. This tool might be important to identify patients with early RA and facilitate a more precise selection of patients for rapid access to rheumatologists.

\footnotetext{
Authors' affiliations

I K Gao, A Haas-Wöhrle, Rheumatology Practice, Heidelberg, Germany K G Mueller, Department of Internal Medicine II, University of Heidelberg, Germany

H-M Lorenz, C Fiehn, Department of Internal Medicine V, University of Heidelberg and Centre for Rheumatic Diseases, Baden-Baden, Germany

Correspondence to: PD Dr C Fiehn, Centre for Rheumatic Diseases Baden-Baden, Rotenbachtalstr. 5, 76530 Baden-Baden, Germany; c.fiehn@rheumazentrum-baden.de
}

Accepted 14 March 2005

\section{REFERENCES}

1 Bas S, Genevay S, Meyer O, Gabay C. Anti-cyclic citrullinated peptide antibodies, $\lg M$ and $\lg A$ rheumatoid factors in the diagnosis and prognosis of rheumatoid arthritis. Rheumatology (Oxford) 2003;42:677-80.

2 Jansen AL, van der Horst-Bruinsma I, van Schaardenburg D, van de Stadt RJ, de Koning MH, Dijkmans BA. Rheumatoid factor and antibodies to cyclic citrullinated peptide differentiate rheumatoid arthritis from undifferentiated polyarthritis in patients with early arthritis. J Rheumatol 2002;29:2074-6.

3 Saraux A, Berthelot JM, Devauchelle V, Bendaoud B, Chales G, Le Henaff C, et al. Value of antibodies to citrulline-containing peptides for diagnosing early rheumatoid arthritis. J Rheumatol 2003;30:2535-9.

4 Zeng X, Ai M, Tian X, Gan X, Shi Y, Song Q, et al. Diagnostic value of anticyclic citrullinated peptide antibody in patients with rheumatoid arthritis. J Rheumatol 2003;30:1451-5.

5 Meyer O, Labarre C, Dougados M, Goupille P, Cantagrel A, Dubois A, et al. Anticitrullinated protein/peptide antibody assays in early rheumatoid arthritis for predicting five year radiographic damage. Ann Rheum Dis 2003;62:120-6.

6 van Gaalen FA, Linn-Rasker SP, van Venrooij WJ, de Jong BA, Breedveld FC, Verweij CL, et al. Autoantibodies to cyclic citrullinated peptides predict progression to rheumatoid arthritis in patients with undifferentiated arthritis: a prospective cohort study. Arthritis Rheum 2004;50:709-15.

7 Lopez-Hoyos M, Ruiz de Alegria C, Blanco R, Crespo J, Pena M, RodriguezValverde V, et al. Clinical utility of anti-CCP antibodies in the differential diagnosis of elderly-onset rheumatoid arthritis and polymyalgia rheumatica. Rheumatology (Oxford) 2004;43:655-7.

8 Kroot EJ, de Jong BA, van Leeuwen MA, Swinkels H, van den Hoogen FH, van't Hof $M$, et al. The prognostic value of anti-cyclic citrullinated peptide antibody in patients with recent-onset rheumatoid arthritis. Arthritis Rheum 2000;43:1831-5.

9 Schellekens GA, Visser $H$, de Jong BA, van den Hoogen FH, Hazes JM, Breedveld FC, et al. The diagnostic properties of rheumatoid arthritis antibodies recognizing a cyclic citrullinated peptide. Arthritis Rheum 2000;43:155-63.

10 Arnett FC, Edworthy SM, Bloch DA, McShane DJ, Fries JF, Cooper NS, et al. The American Rheumatism Association 1987 revised criteria for the classification of rheumatoid arthritis. Arthritis Rheum 1988;31:315-24.

11 Nicolaisen C, Rekvig OP, Nossent HC. Diagnostic value of anti-CCP antibodies in unselected rheumatologic patients [abstract]. Ann Rheum Dis 2004;63(suppl): 191.

\title{
Safety of 15-deoxyspergualin in the treatment of glomerulonephritis associated with active systemic lupus erythematosus
}

\author{
H-M Lorenz, M Grunke, J Wendler, P A Heinzel, J R Kalden
}

Ann Rheum Dis 2005;64:1517-1519. doi: 10.1136/ard.2005.035329

$\mathrm{O}$ ptimal treatment for patients with relapsing lupus nephritis remains unclear. The ability of 15-deoxyspergualin (gusperimus; 15-DSG) to suppress systemic lupus erythematosus (SLE)-like diseases has been demonstrated in animals and humans. ${ }^{1-4}$ 15-DSG exerted no nephrotoxicity or hepatotoxicity but reversibly induced leucocytopenia. ${ }^{5}{ }^{6}$

In this study we aimed at evaluating the safety of 15-DSG in the treatment of glomerulonephritis associated with SLE.

\section{CASE REPORTS}

Table 1 shows the patient characteristics.

15-DSG was provided by Nippon Kayaku Co Ltd, Tokyo, Japan. Patients gave their informed consent, and 15-DSG $0.5 \mathrm{mg} / \mathrm{kg}$ normal body weight (height in $\mathrm{cm}$ minus 100)/day was self administered subcutaneously for 14 days, followed by a break of 7 days ( = 1 cycle). The dose was adjusted (dependent on efficacy or safety, or both) after cycles 4 and 6 to $0.35 \mathrm{mg} / \mathrm{kg}$ and $0.25 \mathrm{mg} / \mathrm{kg}$, or $0.7 \mathrm{mg} / \mathrm{kg}$ and $1.0 \mathrm{mg} / \mathrm{kg}$.

\section{Patient 1}

After a bolus, daily corticosteroids could be decreased to $5 \mathrm{mg}$ after 9 weeks. The patient received six cycles of 15-DSG without major problems. Leucocyte counts were always $>4 \times 10^{9}$ cells/l, no infection was seen, no (serious) adverse events and occurred with the exception of parageusia. GN resolved and her SLE associated activity measures improved (table 1, fig 1). After the sixth cycle the patient was switched from 15-DSG to a combination of ciclosporin A (CSA) and azathioprine, and later azathioprine alone. Renal function was normal at the end of the trial, SELENA-SLEDAI (Safety of Oestrogens in Lupus Erythematosus National AssessmentSLE Disease Activity Index) decreased from 12 to 0 , and the corticosteroid dosage was reduced to $5 \mathrm{mg}$ /day. 


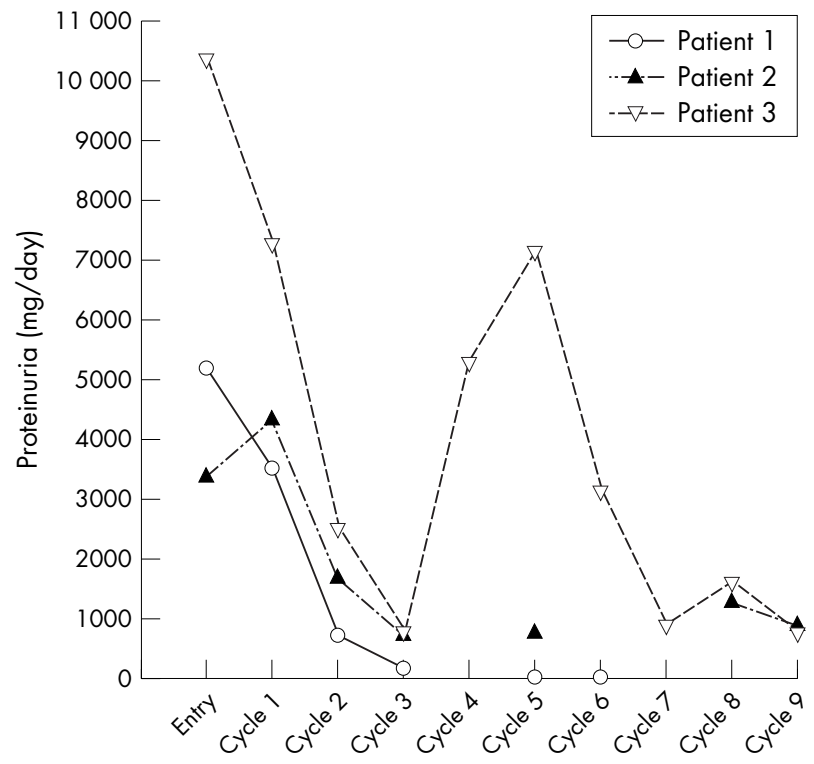

Figure 1 Proteinuria during 15-DSG treatment in patients 1-3. 24 hour urine was collected at the day of entry into the study or the last days of the cycles as indicated. Owing to menstrual bleeding urine collection was not possible in patient 1 at the end of cycle 4 and in patient 2 at the end of cycles 4,6 , and 7 .

\section{Patient 2}

Oral corticosteroids were increased to $40 \mathrm{mg} /$ day and tapered to $5 \mathrm{mg} /$ day within 9 weeks. Proteinuria decreased to $700-$ $750 \mathrm{mg} /$ day (fig l; table 1). During the second cycle, she had herpes zoster exanthema (which completely disappeared after treatment with antiviral agents). The white blood cell count was always $>5 \times 10^{9}$ cells/l. Because dsDNA antibody titres remained high, the 15-DSG dosage was increased to $0.75 \mathrm{mg} / \mathrm{kg} /$ day for cycles 5 and 6 , to $1.0 \mathrm{mg} / \mathrm{kg} /$ day for cycles 7-9. During cycle 5 she experienced bacterial bronchitis without fever. At the end of cycle 6 her anaemia worsened (possibly 15-DSG-related?). ${ }^{7}$ Within the ninth cycle, for the first time during treatment with 15-DSG, the urine sediment indicated a flare of GN. At this time, proteinuria was $890 \mathrm{mg} /$ day (fig 1); creatinine was always normal. SELENA-SLEDAI decreased from 12 to 4 (end of cycle 8 ). The corticosteroid dosage was $5 \mathrm{mg} /$ day at the end of the study.
Treatment was switched to $150 \mathrm{mg}$ oral cyclophosphamide. During her last visit to our clinic the anaemia had improved $(115 \mathrm{~g} / \mathrm{l})$, proteinuria was stable $(1100 \mathrm{mg} / \mathrm{day})$, and erythrocyturia was present without signs of active GN.

\section{Patient 3}

After a bolus, corticosteroids could be tapered to $5 \mathrm{mg}$ /day (end of cycle 3). Maximum proteinuria was $10300 \mathrm{mg} / \mathrm{day}$ at entry into 15-DSG treatment (fig 1; table 1). By the end of cycle 3, proteinuria had decreased to $<1000 \mathrm{mg}$ /day (fig l). Within cycles 3 and 4 she had a prolonged urogenital infection, possibly related to leucocytopenia $\left(3.9 \times 10^{9}\right.$ cells $/ 1$ at the end of cycle $3,1.7 \times 10^{9}$ cells/l at the end of cycle 4 ). She now experienced a flare of her GN (increased proteinuria up to $7100 \mathrm{mg} /$ day at the end of cycle 5; fig 1 ). We increased the corticosteroids to $60 \mathrm{mg} /$ day, continued 15-DSG as previous success was excellent, but decreased the dosage to $0.35 \mathrm{mg} /$ $\mathrm{kg}$ /day because of (possibly 15-DSG-related?) leucocytopenia and the infectious episodes. In addition, we prescribed low dose CSA ( $2.5 \mathrm{mg} / \mathrm{kg} / \mathrm{day})$ as 15 -DSG had been successfully used together with CSA. ${ }^{8}$ Subsequently, corticosteroids could be tapered to $5 \mathrm{mg}$ /day within 7 weeks. Proteinuria decreased to $780 \mathrm{mg} /$ day (cycle 9; fig 1); creatinine was always normal. No infections were reported during the 15DSG + CSA treatment. She is now receiving CSA alone. SELENA-SLEDAI decreased from 14 to 6; the corticosteroid dosage was reduced to $5 \mathrm{mg} /$ day at the end of the study.

\section{CONCLUSION}

As far as we know, this is the first report on safety of 15-DSG in the treatment of active SLE-GN. Two of the three patients had non-severe infectious episodes, but otherwise 15-DSG was well tolerated. We are currently conducting a phase I/II trial with 15-DSG in patients with SLE and active GN which will also focus on efficacy measurement.

\section{ACKNOWLEDGEMENTS}

We thank our patients for their collaboration and help in performing this trial.

\section{Authors' affiliations}

H-M Lorenz, Division of Rheumatology, Department of Medicine V, University of Heidelberg, Heidelberg, Germany

Table 1 Details of the patients' history, especially previous immunosuppressive treatment, signs of SLE-GN activity or general SLE activity at entry, and indicators for response during/after 15-DSG treatment

\begin{tabular}{|c|c|c|c|c|c|c|c|}
\hline $\begin{array}{l}\text { Patient } \\
\text { No }\end{array}$ & $\begin{array}{l}\text { Age } \\
\text { (years) }\end{array}$ & $\begin{array}{l}\text { First } \\
\text { diagnosed }\end{array}$ & $\begin{array}{l}\text { Organ involvement } \\
\text { in history and } \\
\text { diagnostic criteria }\end{array}$ & Previous treatment & $\begin{array}{l}\text { Signs of SLE-GN activity/general } \\
\text { SLE activity }\end{array}$ & Indicators for response & Additional comments \\
\hline 1 & 49 & 1975 & $\begin{array}{l}\text { Pericarditis, mesangial } \\
\text { GN (biopsy } 4 \text { years } \\
\text { before 15-DSG), } \\
\text { pulmonary involvement, } \\
\text { arthralgias, serology }\end{array}$ & $\begin{array}{l}\text { CYC IV or CYC by mouth } \\
1986-90, \text { CSA 1990-96, } \\
\text { plasma exchange } \\
\text { intermittently, chloroquine } \\
\text { plus leflunomide 1997-98, } \\
\text { CSA, in part with UP394, } \\
\text { 1999-2002 }\end{array}$ & $\begin{array}{l}\text { Increasing proteinuria (max } 8 \mathrm{~g} / \\
\text { day), active urine sediment, } \\
\text { increase of serum creatinine (max } \\
120 \mu \mathrm{mol} / \mathrm{l}) \text {, arterial hypertension, } \\
\text { anaemia, dsDNA Ab titres rising, } \\
\mathrm{C} 3 / \mathrm{C} 4 \text { decreased/arthralgias }\end{array}$ & $\begin{array}{l}\text { Loss of proteinuria and haematuria, } \\
\text { detection of auto-Ab, arthralgias, C3, C4 } \\
\text { normal, serum creatinine normal } \\
\text { improvement in: anaemia (with } \\
\text { erythropoietin support), C3,C4, arterial } \\
\text { hypertension required steroid dosage, } \\
\text { TLCO stable }\end{array}$ & $\begin{array}{l}\text { 15-DSG } 0.5 \mathrm{mg} / \mathrm{kg} / \mathrm{day} \text { for } 6 \\
\text { cycles, followed by AZA plus } \\
\text { CSA, later AZA alone }\end{array}$ \\
\hline 2 & 23 & 1993 & $\begin{array}{l}\text { Mesangioproliferative } \\
\text { GN, later diffuse } \\
\text { proliferative mesangial } \\
\text { GN (biopsy } 3 \text { months } \\
\text { before 15-DSG), } \\
\text { arthralgias, serology }\end{array}$ & $\begin{array}{l}\text { CYC IV 1993-94, MTX } \\
\text { 1994-95, AZA 1995- } \\
2002 \text {, CYC IV } 2002\end{array}$ & $\begin{array}{l}\text { Increasing proteinuria despite CYC } \\
\text { (max } 6 \mathrm{~g} / \text { day), active urine } \\
\text { sediment, arterial hypertension, } \\
\text { anaemia, dsDNA Ab titres rising, } \\
\mathrm{C} 3 / \mathrm{C} 4 \text { decreased/arthralgias, } \\
\text { fatigue }\end{array}$ & $\begin{array}{l}\text { Loss of oedema, fatigue, arthralgias, } \\
\text { active urine sediment, arterial } \\
\text { hypertension improvement in: proteinuria } \\
(1.1 \mathrm{~g} / \text { day) anaemia, required steroid } \\
\text { dosage unchanged: dsDNA Ab titres, C3, } \\
\text { C4 }\end{array}$ & $\begin{array}{l}15-\text { DSG } 0.5 \mathrm{mg} / \mathrm{kg} / \text { day cycles } \\
1-4,0.75 \mathrm{mg} / \mathrm{kg} / \text { day cycles } \\
5+6,1 \mathrm{mg} / \mathrm{kg} / \text { day cycles } 7-9 ; \\
\text { herpes zoster cycle } 2 \text {, bacterial } \\
\text { bronchitis cycles } 5+6 \text {, GN flare } \\
\text { at the end of cycle } 9 \text { during } 15- \\
\text { DSG treatment }\end{array}$ \\
\hline 3 & 29 & 1998 & $\begin{array}{l}\text { Arthritis, } \\
\text { leucocytopenia, malar } \\
\text { rash, serology, } \\
\text { mesangial GN (biopsy } \\
2 \text { months before } \\
\text { 15-DSG) }\end{array}$ & $\begin{array}{l}\text { Antimalarial drugs 1998- } \\
99, \text { MTX 1999-2000, AZA } \\
\text { 2000, CYC IV 2000-01, } \\
\text { AZA 2001-02, MMF } \\
\text { 2002-03 }\end{array}$ & $\begin{array}{l}\text { Increasing proteinuria despite MMF } \\
\text { (max. } 10,3 \mathrm{~g} / \text { day), active urine } \\
\text { sediment, arterial hypertension, } \\
\text { anaemia, dsDNA Ab titres rising, } \\
\mathrm{C} 3 / \mathrm{C} 4 \text { decreased, oedema/rash, } \\
\text { leucocyłopenia, mucosal ulcers, } \\
\text { arthralgias, night sweat }\end{array}$ & $\begin{array}{l}\text { Loss of oedema, anaemia, arthralgias, } \\
\text { haematuria, mucosal ulcers, night sweat } \\
\text { improvement in: proteinuria }(0.78 \mathrm{~g} / \\
\text { day), C3, C4, dsDNA Ab, required } \\
\text { steroid dosage, arterial hypertension } \\
\text { unchanged: rash, leucocytopenia (15- } \\
\text { DSG + SLE induced), Sm-, RNP-Ab }\end{array}$ & $\begin{array}{l}\text { 15-DSG } 0.5 \mathrm{mg} / \mathrm{kg} / \text { day cycles } \\
\text { 1-4, flare cycles } 4+5 \text { after } \\
\text { infection (leucocytopenia!), } \\
\text { steroids increased, } 15 \text {-DSG } \\
0.35 \mathrm{mg} / \mathrm{kg} / \text { day +CSA cycles } \\
5-9\end{array}$ \\
\hline
\end{tabular}

CYC, cyclophosphamide; CSA, ciclosporin A; MTX, methotrexate; AZA, azathioprine, MMF, mycophenolate mofetil. 
M Grunke, J Wendler, J R Kalden, Department of Medicine III and Institute for Clinical Immunology, University of Erlangen-Nuremberg, Erlangen, Germany

P A Heinzel, Euro Nippon Kayaku, Frankfurt, Germany

PAH is an employee of Euro Nippon Kayaku, a branch of the mother company Nippon Kayaku, Tokyo, Japan, which provided the drug for this trial free of charge.

Treatment of SLE-GN with 15-DSG was approved by the local ethics committee.

Correspondence to: Professor H-M Lorenz, Division of Rheumatology, Department of Medicine V, University of Heidelberg, Im Nevenheimer Feld 410, 69120 Heidelberg, Germany; Hannes_Lorenz@ med.uni-heidelberg.de

Accepted 15 March 2005

\section{REFERENCES}

1 Nemoto K, Mae T, Saiga K, Matsuura E, Koike T. Autoimmune-prone $(\mathrm{NZW} \times \mathrm{BXSB}) \mathrm{F} 1(\mathrm{~W} / \mathrm{BF} 1)$ mice escape severe thrombocytopenia after treatment with deoxyspergualin, an immunosuppressant. $\mathrm{Br} J$ Haematol 1995;91:691-6.

2 Amemiya H, Koyama I, Kyo M, Kozaki K, Yuzawa K, Sakamoto K, et al. Outline and long-term prognosis in 15-deoxyspergualin-treated cases. Japan Collaborative Transplant Study Group of NKT-01. Transplant Proc 1996;28:1156-8

3 Hotta O, Furuta T, Chiba S, Yusa N, Taguma Y. Immunosuppressive effect of deoxyspergualin in proliferative glomerulonephritis. Am J Kidney Dis 1999;34:894-901

4 Birck R, Warnatz K, Lorenz H-M, Choi M, Haubitz M, Grunke M, et al. 15Deoxyspergualin in patients with refractory ANCA-associated systemic vasculitis: a six-month open-label trial to evaluate safety and efficacy. J Am Soc Nephrol 2003; 14:440-7.

5 Gores PF. Deoxyspergualin: clinical experience. Transplant Proc 1996;28:871-2.

6 Ramos EL, Nadler SG, Grasela DM, Kelley SL. Deoxyspergualin: mechanism of action and pharmacokinetics. Transplant Proc 1996;28:873-5.

7 Nemoto K, Ogino M, Ohinata A, Hirashima K. Unique action of an immunosuppressive agent, deoxyspergualin, on hematopoiesis in mice. Exp Hematol 1997;25:1339-46.

8 Seki T, Tanda K, Chikaraishi T, Takeuchi I, Kanagawa K, Togashi M, et al. Addition of deoxyspergualin to standard triple immunosuppressive regimen in kidney transplantation. Transplant Proc 1996;28:1352-3.

\section{Autoimmune hepatitis associated with infliximab in a patient with psoriatic arthritis}

\section{Germano, A Picchianti Diamanti, G Baccano, E Natale, A Onetti Muda, R Priori, G Valesini}

W read with interest the debate about liver toxicity of infliximab in psoriatic arthritis (PsA). ${ }^{12}$ We describe the case of a 53 year old woman with a 4 year history of refractory PsA who developed transaminasitis during infliximab treatment.

\section{CASE REPORT}

Despite combination treatment (ciclosporin $300 \mathrm{mg} /$ day, fluocortolone $10 \mathrm{mg} /$ day, and methotrexate (MTX) $15 \mathrm{mg} /$ week intramuscularly), disease activity was still high, and intravenous infliximab at $3 \mathrm{mg} / \mathrm{kg}$ was administered initially at weeks 0, 2, 6, 14 and then every 6 weeks. Ciclosporin was withdrawn.

Within 3 weeks she improved, fluocortolone was gradually stopped while methotrexate (MTX) $20 \mathrm{mg} /$ week intramuscularly, was continued. After the sixth infusion, she developed a mild transaminasitis and MTX, initially tapered, was stopped. After the eighth infusion transaminases continued to rise and in the absence of any other plausible cause, infliximab was withdrawn.

She was admitted to our department with persistently high values of aspartate aminotransferase and alanine aminotransferase and a flare of PsA.

The erythrocyte sedimentation rate was $30 \mathrm{~mm} / \mathrm{lst} \mathrm{h}, \mathrm{C}$ reactive protein $170 \mathrm{mg} / \mathrm{l}$, aspartate aminotransferase $143 \mathrm{IU}$ (normal 5-40), alanine aminotransferase 234 IU (normal 555), anti-parietal cell antibodies and liver and kidney microsomal antigen were absent, and serology for hepatitis viruses, cytomegalovirus and Epstein-Barr virus, was negative. The new appearance of anti-dsDNA (IgG) $1 / 20$ (indirect immunofluorescence on Crithidia luciliae), antismooth muscle antibodies (ASMA) 1/640 was observed, while the titre of antinuclear antibodies (ANA), previously present at a serum dilution of $1 / 80$, increased to $1 / 160$. Liver ultrasonography showed steatosis. A liver biopsy revealed intense and diffuse portal lymphoplasmacytic, granulocytic inflammatory infiltration and severe interface hepatitis. Mild periportal fibrosis was also evident (figs $1 \mathrm{~A}$ and B). Fluocortolone $20 \mathrm{mg}$ daily was started and the joints improved. Within a few months, transaminases declined and finally normalised; ANA remained positive, while antidsDNA and ASMA disappeared.

\section{DISCUSSION}

Feletar et al found a high incidence of liver toxicity in patients with PsA treated with infliximab, ${ }^{1}$ even if, as Provenzano pointed out, ${ }^{2}$ in some cases this association was debatable because of the concomitant use of MTX and the lack of exclusion of viral infections. In one of the largest studies on the use of infliximab in rheumatoid arthritis (RA), ${ }^{3}$ no liver disease was recorded, but recently two possible cases of liver disease associated with infliximab use have been observed in Crohn's disease and PsA. ${ }^{4}$ In our patient the chronological relationship between transaminasitis and treatment (fig 2), linked to the peculiar histology, is suggestive of autoimmune hepatitis induced by infliximab. The high titre of ASMA, notoriously associated with autoimmune hepatitis, ${ }^{6}$ supports this hypothesis.

Our patient was concomitantly treated with MTX for almost 30 weeks. MTX can produce steatosis, fibrosis and, ultimately, cirrhosis; its hepatotoxicity in psoriasis is well known. A 2.5-5.0-fold increase in liver damage for psoriasis compared with RA has been reported.

Moreover, patients with PsA seem more prone to liver toxicity during infliximab treatment than those with RA. ${ }^{1} \mathrm{~A}$ dissimilar toxicity profile for disease modifying antirheumatic drugs in various diseases has been linked to differences in pathophysiology, genetic background, drinking behaviour, and age. 

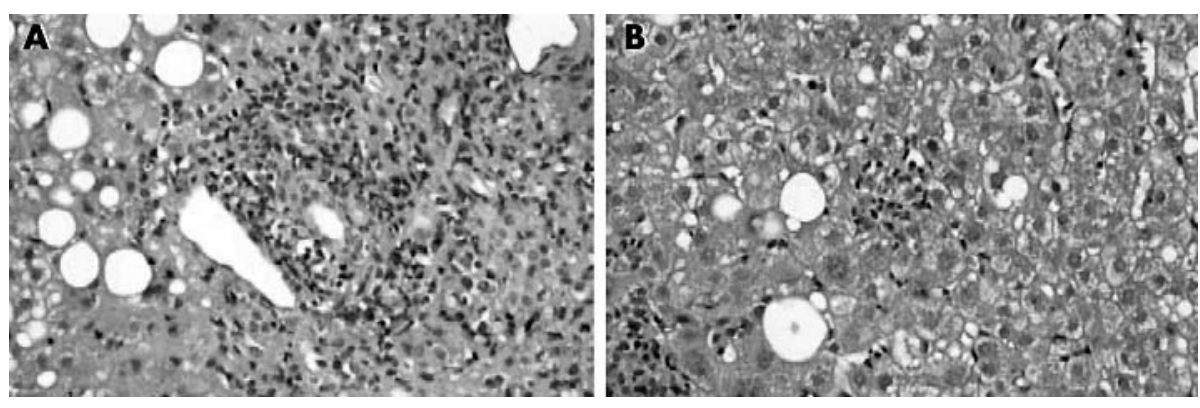

Figure 1 (A) A liver biopsy revealed intense and diffuse portal lymphoplasmacytic, granulocytic inflammatory infiltration and severe interface hepatitis; Diffuse macro-microvesicular steatosis (over $60 \%$ hepatocytes), intranuclear glycogen accumulation, and hyaline degeneration of hepatocytes (Mallory bodies) were also noted. Mild periportal fibrosis was evident with formation of incomplete septa and perisinusoidal and perivenular fibrosis. (B) Lobular evidence of confluent necrosis and inflammatory infiltrates.

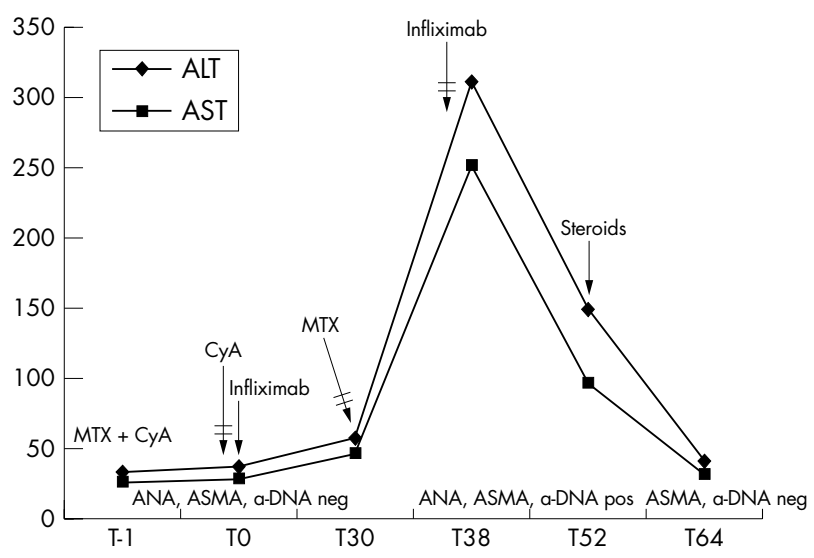

Figure 2 Chronological relationship between transaminasitis and infliximab in the patient. AST, aspartate aminotransferase; ALT, alanine aminotransferase; T, time in weeks; MTX, methotrexate; CyA, ciclosporin A; ANA, antinuclear antibodies; ASMA, anti-smooth muscle antibodies; a-DNA, anti-DNA antibodies.

However, our patient had received less than a third (900 $\mathrm{mg}$ in the past 4 years) of the cumulative dose known to be a risk for hepatic toxicity. ${ }^{8}$ In this case, infliximab might have led to the acute damage-that is, severe portal inflammation and initial neoductulogenesis, whereas MTX might have been responsible for the chronic hepatic injurythat is, mild fibrosis and steatosis. The introduction of corticosteroids probably hastened liver recovery with subsequent normalisation of transaminases.

The appearance of autoantibodies, occasionally associated with mild and transitory autoimmune diseases, during antitumour necrosis factor $\alpha$ treatment has been documented ${ }^{19}$ and reflects the complex relationship between tumour necrosis factor $\alpha$ blockage and autoimmunity. This report confirms the need to monitor liver enzymes carefully and perform liver biopsy, if necessary, not only in patients with PsA using combination treatment with MTX and infliximab but also for those using infliximab alone, especially in the presence of pre-existent serological signs of autoimmunity such as ANA. Such signs might be a risk factor for further development of clinical autoimmunity during infliximab treatment.

\section{Authors' affiliations \\ V Germano, A Picchianti Diamanti, G Baccano, R Priori, G Valesini, Division of Rheumatology, University of Rome "La Sapienza", Italy E Natale, A Onetti Muda, Department of Experimental Medicine and Pathology, University of Rome "La Sapienza", Rome}

Correspondence to: Professor G Valesini, Divisione di Reumatologia, Dipartimento di Terapia e Clinica Medica Applicata, Policlinico Umberto I, Viale del Policlinico, 00161 Roma, Italy; g.valesini@uniroma1.it

Accepted 14 March 2005

\section{REFERENCES}

1 Feletar M, Brockbank JE, Schentag CT, Lapp V, Gladman DD. Treatment of refactory psoriatic arthrtis with infliximab: a 12 month observational study of 16 patients. Ann Rheum Dis 2004;63:156-61.

2 Provenzano G. Liver toxicity of infliximab in psoriatic arthritis. Ann Rheum Dis 24 June 2004; e-letter.

3 St Clair EW, Wagner CL, Fasanmade AA, Wang B, Schaible T, Kavanaugh A, et al. The relationship of serum infliximab concentrations to clinical improvement in rheumatoid arthritis: results from ATTRACT, a multicenter, randomized, double-blind, placebo-controlled trial. Arthritis Rheum 2002;46:1451-9.

4 Saleem G, Li SC, MacPherson BR, Cooper SM. Hepatitis with interface inflammation and $\lg G, \lg M$, and $\lg A$ anti ds-DNA antibodies following infliximab therapy. Arthritis Rheum 2001;44:1966-8.

5 Menghini VV, Arora AS. Infliximab-associated reversible cholestatic liver disease. Mayo Clin Proc 2001;76:84-6.

6 Vergani D, Mieli-Vergani G. Autoimmune hepatitis. Autoimmun Rev 2003;2:241-7.

7 Whiting-O'Keefe QE, Fye KH, Sack KD. Methotrexate and histologic hepatic abnormalities: a meta analysis. Am J Med 1991;90:711-16.

8 Aithal GP, Haugh B, Das S, Card T, Burt AD, Record CO. Monitoring methotrexate-induced hepatic fibrosis in patients with psoriasis: are serial liver biopsies justified? Aliment Pharmacol Ther 2004;19:391-9.

9 De Rycke L, Kruithof E, Van Damme N, Hoffman EA. Van den Bossche, Van den Bosch F, et al. Antinuclear antibodies following infliximab treatment in patients with rheumatoid arthritis or spondylarthropathy. Arthritis Rheum 2003;48:1015-23. 


\title{
Alleviation of polyarticular syndrome in multicentric reticulohistiocytosis with intravenous zoledronate
}

\author{
C P Mavragani, K Batziou, K Aroni, D Pikazis, M N Manoussakis
}

Ann Rheum Dis 2005;64:1521-1522. doi: 10.1136/ard.2004.032433

$\Lambda$ 67 year old previously healthy women presented with a 12 month history of generalised symmetric arthralgias and bilateral hand contractures. Her past medical history was unremarkable, except for heavy smoking.

On physical examination, she had tight incapacitating flexion contractures of both hands, and small cutaneous nontender well circumscribed nodules (3-6 mm diameter) on the dorsum of the fingers and over the proximal and distal interphalangeal joints (fig 1). A symmetric polyarthritis affecting the shoulders, elbows, proximal and distal interphalangeal joints, and the knees was prominent. Blood counts, biochemical profile and inflammatory markers, antinuclear antibodies, and rheumatoid factor were within normal limits. A hand $x$ ray examination showed erosive deforming arthropathy of the styloid processes. Biopsy samples of a skin nodule and of synovial membrane disclosed infiltrates of multinucleated giant cells and histiocytes, indicative of multicentric reticulohistiocytosis (MRH). The infiltrating histiocytes were macrophages, as illustrated by positive staining for CD68 marker and negative staining for S-100 (Langerhans' dendritic cell marker) and HHF-35 actin (fibroblast marker).

The well described association of MRH with malignancies $^{12}$ had prompted the screening for underlying malignancies, which disclosed a 10-fold increase of CA-125. A pelvic computed tomographic scan was normal; however, magnetic resonance imaging showed the presence of a small well circumscribed mass at the left parametrial space, which was subsequently removed by laparotomy and diagnosed as poorly differentiated ovarian adenocarcinoma without metastatic spread. The patient was given intravenous combination treatment of carbaplatine and cyclophosphamide.

Three months later, the cutaneous nodules resolved, but the polyarthritis persisted and the patient gradually developed a generalised painful stiffness of the trunk and extremities, which required the use of narcotic analgesics

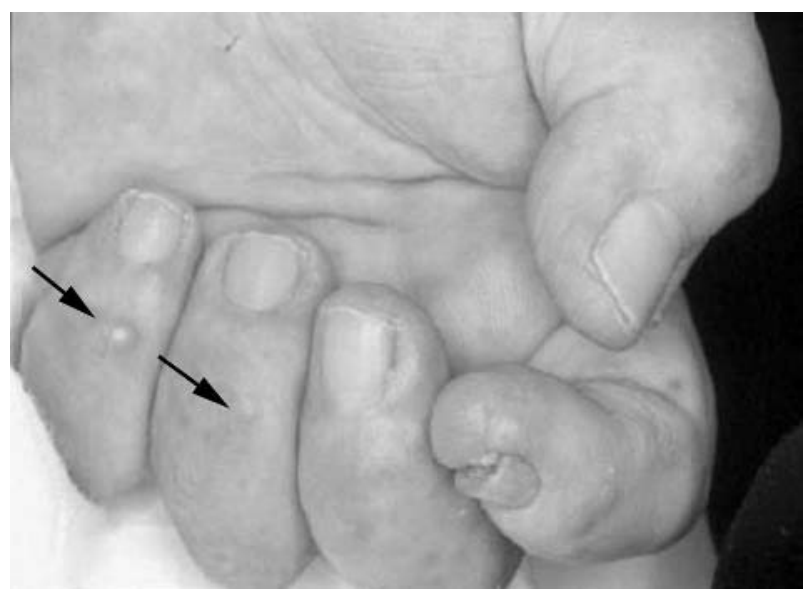

Figure 1 Contraction flexures and cutaneous nodules in the dorsum of the fingers (arrows). and confined her to bed. Intravenous methylprednisolone pulses were also administered, without response. Based on the recently reported effectiveness of intravenous alendronate for $\mathrm{MRH},{ }^{3}$ zoledronate $(4 \mathrm{mg}$ ) was given intravenously, because alendronate was unavailable locally. Two weeks later, the stiffness and arthralgias were dramatically reduced. The patient is now completely free of pain and ambulatory.

\section{DISCUSSION}

MRH is a rare disorder of unknown cause, characterised by destructive symmetric arthritis associated with cutaneous papulonodular lesions. In about one third of patients, musculoskeletal symptoms may precede or follow an underlying malignancy (such as breast and ovarian cancer, melanoma or mesothelioma). ${ }^{2}$ MRH should be differentiated from fibroblastic rheumatism, which is also rare. ${ }^{4}$ Although strict differentiating histological criteria are lacking, multinucleated foreign body-type giant cells appear to denote MRH, whereas the predominance of myofibroblasts and excessive collagen production characterises fibroblastic rheumatism. ${ }^{5}$ The inclusion of fibroblastic rheumatism in the broader spectrum of non-Langerhans' cell histiocytosis has been recently proposed. ${ }^{6}$

To date, the decision for systemic therapeutic intervention in MRH remains largely empirical. Treatment with steroids and various cytotoxic agents is of questionable efficacy, ${ }^{2}$ and in our patient it resulted only in resolution of the cutaneous nodules. Recently, the beneficial role of tumour necrosis factor blockers has been suggested ${ }^{7}$; however, these are contraindicated in patients with concomitant neoplasia. Intravenous alendronate has been also advocated in the management of MRH. ${ }^{4}$ In our patient, the administration of the parenteral bisphosphonate zoledronate, so far used for the treatment of osteoporosis ${ }^{8}$ and of hypercalcaemia of malignancy, ${ }^{9}$ dramatically alleviated the incapacitating joint symptoms.

The precise mechanism of bisphosphonate action on MRH is unclear. However, after intravenous injection, bisphosphonates have been previously shown to deposit in the reticuloendothelial system, ${ }^{10}$ to inhibit the metalloprotease activity and matrix metalloproteinase-9 expression of infiltrating macrophages, ${ }^{11}$ and to induce apoptosis of macrophage-like cells. ${ }^{12}$ Therefore, one may speculate that their favourable effect in MRH is due to the inhibition of tissue infiltration by histiocytes, possibly through induction of apoptosis.

\section{ACKNOWLEDGEMENTS}

We are indebted to Professor HM Moutsopoulos for inspiration and fruitful suggestions.

\section{Authors' affiliations}

C P Mavragani, K Batziou, D Pikazis, M N Manoussakis, Department of Pathophysiology, Medical School, National University School of Athens, Athens, Greece

K Aroni, Department of Pathology, Medical School, National University School of Athens, Athens, Greece 
Correspondence to: Associate Professor M N Manoussakis, Department of Pathophysiology, Medical School, National University School of Athens, M Asias 75, 11527, Athens, Greece; menman@med.voa.gr

Accepted 21 March 2005

\section{REFERENCES}

1 Barrow MV, Holubar K. Multicentric reticulohistiocytosis. A review of 33 patients. Medicine (Baltimore) 1969;48:287-305.

2 Gorman JD, Danning C, Schumacher HR, Klippel JH, Davis JC Jr. Multicentric reticulohistiocytosis: case report with immunohistochemical analysis and literature review. Arthritis Rheum 2000;43:930-8

3 Goto H, Inaba M, Kobayashi K, Imanishi Y, Kumeda Y, Inui K, et al. Successful treatment of multicentric reticulohistiocytosis with alendronate: evidence for a direct effect of bisphosphonate on histiocytes. Arthritis Rheum 2003;48:3538-41.

4 Romas $E$, Finlay $M$, Woodruff T. The arthropathy of fibroblastic rheumatism. Arthritis Rheum 1997;40:183-7.
5 Fam AG, Hanna W, Mak V, Assaad D. Fibroblastic rheumatism: clinical and histologic evolution of cutaneous manifestations. J Rheumatol 1998:25:2261-6.

6 Zelger B, Burgdorf W. Fibroblastic rheumatism: a variant of non-Langerhans cell histiocytoses? Pediatr Dermatol 2003;20:461-2.

7 Matejicka C, Morgan GJ, Schlegelmilch JG. Multicentric reticulohistiocytosis treated successfully with an anti-tumor necrosis factor agent: comment on the article by Gorman et al. Arthritis Rheum 2003:48:864-6.

8 Perry CM, Figgitt DP. Zoledronic acid: a review of its use in patients with advanced cancer. Drugs 2004;64:1197-211.

9 Reid IR, Brown JP, Burckhardt P, Horowitz Z, Richardson P, Trechsel U, et al. Intravenous zoledronic acid in postmenopausal women with low bone mineral density. N Engl J Med 2002:346:653-61.

10 Monkkonen J, Koponen HM, Ylitalo P. Comparison of the distribution of three bisphosphonates in mice. Pharmacol Toxicol 1990;66:294-8.

11 Giraudo E, Inove M, Hanahan D. An amino-bisphosphonate targets MMP-9expressing macrophages and angiogenesis to impair cervical carcinogenesis. $J$ Clin Invest 2004;114:623-33.

12 Rogers MJ, Chilton KM, Coxon FP, Lawry J, Smith MO, Suri S, et al. Bisphosphonates induce apoptosis in mouse macrophage-like cells in vitro by a nitric oxide-independent mechanism. J Bone Miner Res 1996;11:1482-91.

\section{Acetaminophen may act through $\beta$ endorphin}

\section{H Sprott, H Shen, S Gay, A Aeschlimann}

A cetaminophen, also known as paracetamol, is a nonsteroidal anti-inflammatory drug (NSAID) with potent antipyretic and analgesic actions but with very weak anti-inflammatory activity. The mechanism of action of acetaminophen is still not clearly understood. It has no known endogenous high affinity binding sites. In addition, acetaminophen does not appear to share with NSAIDs the ability to inhibit peripheral cyclo-oxygenase (COX) activity. ${ }^{1}$ Although various biochemical studies point to inhibition of central COX-2 activity, the existence of a COX activity that is selectively susceptible to acetaminophen (COX-3?) is an alternative hypothesis. ${ }^{2}$ However, this may hold true only for the dog. Database analysis of human COX-1 showed a frame shift induced by intron 1, possibly showing COX-3 to be a virtual protein in humans.

Our studies in osteoarthritis provide evidence of a clear effect of acetaminophen on $\beta$ endorphin levels in plasma (fig 1) compared with rofecoxib $25 \mathrm{mg} /$ day. ${ }^{4}$ Plasma $\beta$ endorphin levels decreased in 10 patients with osteoarthritis after 1 month of treatment with up to $4 \mathrm{~g}$ /day acetaminophen orally $(p=0.017)$ as well as after 3 months of treatment $(p=0.028)$. Whereas, there were no changes in the rofecoxib group after 1 month $(p=0.73)$ and 3 months $(\mathrm{p}=1.00)$, respectively.

Acetaminophen may play a part in the delivery of peripheral $\beta$ endorphin to their receptors and thereby relieve pain.

\section{Authors' affiliations \\ H Sprott, H Shen, S Gay, Centre of Experimental Rheumatology, Department of Rheumatology and Institute of Physical Medicine, University Hospital Zurich, Switzerland}

A Aeschlimann, RehaClinic Zurzach, CH-5330 Zurzach, Switzerland

Correspondence to: Dr H Sprott, Centre of Experimental Rheumatology, Department of Rheumatology and Institute of Physical Medicine, University Hospital, Gloriastrasse 25, CH-8091 Zurich, Switzerland; haiko.sprott@usz.ch

Accepted 7 February 2005

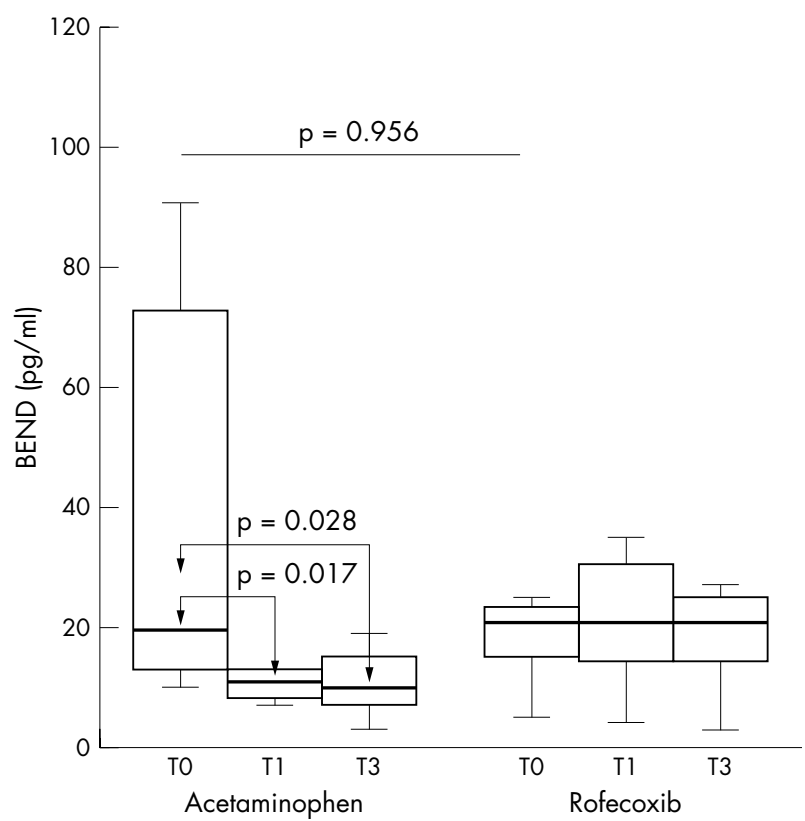

Figure 1 Acetaminophen reduces plasma $\beta$ endorphin levels in patients with symptomatic osteoarthritic (box plot graphs). BEND, $\beta$ endorphin; TO, basic values (no significant difference between the groups,

$\mathrm{p}=0.965)$; $\mathrm{T} 1$, plasma levels after $1 \mathrm{month}$ 's oral treatment; $\mathrm{T} 3$, plasma levels after 3 months' oral treatment.

\section{REFERENCES}

1 Bonnefont J, Courade JP, Alloui A, Eschalier A. [Antinociceptive mechanism of action of paracetamol.] Drugs 2003;63(Spec No 2): 1-4.

2 Botting RM. Mechanism of action of acetaminophen: is there a cyclooxygenase 3? Clin Infect Dis 2000;31(suppl 5):S202-10.

3 Schwab JM, Beiter T, Linder JU, Laufer S, Schulz JE, Meyermann R, et al. COX-3-a virtual pain target in humans? FASEB J 2003;17:2174-5.

4 Shen H, Sprott H, Aeschlimann A, Gay RE, Uebelhart D, Michel BA, et al. Primary analgesic action of acetaminophen and rofecoxib in osteoarthritis. Ann Rheum Dis 2003;62(suppl I):258 


\title{
Refractory adult onset Still's disease and hypersensitivity to non-steroidal anti-inflammatory drugs and cyclo-oxygenase- 2 inhibitors: are biological agents the solution?
}

\author{
E H J G Aarntzen, P L C M van Riel, P Barrera
}

A dult onset Still's disease (AOSD) is an autoimmune disorder characterised by periodic high fever, arthritis, and typical evanescent rashes. Non-steroidal antiinflammatory drugs (NSAIDs) are the preferred treatment. In severe cases several disease modifying antirheumatic drugs, thalidomide, and intravenous immunoglobulin have been used. More recently, successful treatment with tumour necrosis factor $\alpha(\mathrm{TNF} \alpha)$ blocking agents ${ }^{12}$ and interleukin (IL) 1 neutralisation ${ }^{3}$ has also been reported.

Hypersensitivity to NSAIDs, often characterised by urticaria, angio-oedema, and asthma, has been well documented, and several studies indicate that anaphylactic reactions are related to the inhibition of cyclo-oxygenase-1 (COX-1) enzyme $^{4-6}$ and that selective COX-2 inhibitors can be safe in these patients. Here we report a case of AOSD complicated by coexisting hypersensitivity to acetaminophen (paracetamol), aspirin, NSAIDs, and also to selective COX-2 inhibitors. TNF $\alpha$ neutralisation controlled the fever, but not the AOSD related rashes and polyarthritis or the anaphylactic reactions to NSAIDs and COX-2 inhibitors. Treatment with ILl receptor antagonist led to full remission of the AOSD.

\section{CASE REPORT}

A patient, with known AOSD for 22 years, was admitted to our centre with a 3 week history of spiking high fever, chills, skin rash, cough, and a sore throat. Physical examination disclosed a typical AOSD related rash, polyarthritis, and enlarged inguinal lymph nodes without hepatosplenomegaly. Laboratory examination showed an increased acute phase reaction and a normochromic normocytic anaemia; white blood cell count, platelet count, and liver function tests were normal. Serological tests for viral infections, toxoplasma, Bartonella, blood and urine culture rheumatoid factor, and antinuclear antibodies were all negative.

In the past the AOSD had followed a polycyclic course, which had been successfully treated with several NSAIDs alone or in combination with acetaminophen for 10 years. In 1993, she developed an allergic reaction with angio-oedema to naproxen (fig 1), and later also to acetaminophen and sodium salicylate. Methotrexate was used for the next 10 years, but frequently corticosteroids were needed to treat the AOSD exacerbations. To avoid chronic use of corticosteroids, etanercept was started in May 2003 and the corticosteroids were tapered. This led to exacerbations of a mild polyarthritis and worsening of the rash but no fever. Because selective COX-2 inhibitors may be safe in patients with intolerance to NSAIDs, ${ }^{45}$ rofecoxib was successfully added to etanercept without intolerance. However, a second challenge with rofecoxib resulted in severe angiooedema and urticarial rash and the same occurred after challenges with celecoxib and etoricoxib. ILl receptor antagonist was started in December 2004, leading to a full remission of all AOSD related symptoms despite the withdrawal of long term steroid treatment.

\section{DISCUSSION}

Our case illustrates that TNF $\alpha$ blocking agents are only partially effective in the treatment of refractory AOSD. Partial or limited efficacy of these agents has also been also observed in patients with systemic onset juvenile idiopathic arthritis. ${ }^{78}$ Our case and several other reports suggest that it is not TNF $\alpha$
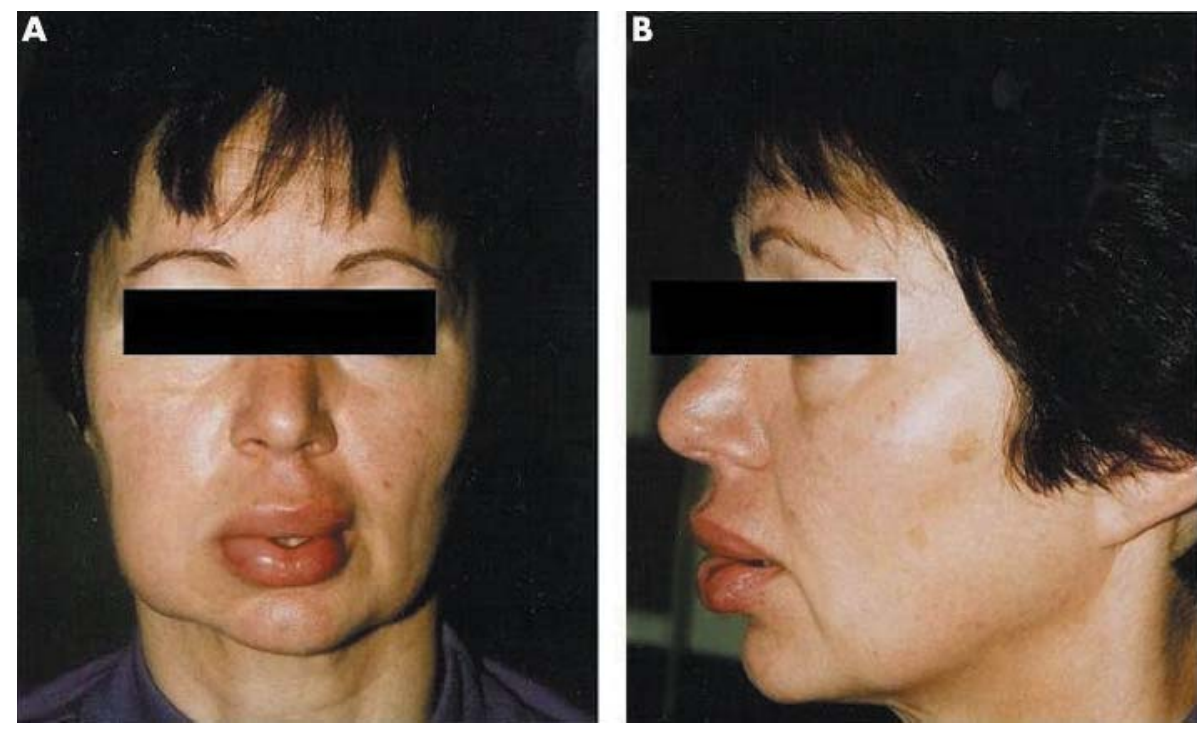

Figure 1 Angio-oedema after NSAID ingestion. Reproduced with the patient's permission. 
but ILl which has a pivotal role in the pathogenesis of AOSD 3 and systemic onset juvenile idiopathic arthritis. ${ }^{9}$ In these diseases and in other rare disorders with a single amino acid mutation in the NALP-3 gene which results in increased ILl secretion, ILl blockade seems to be the preferred treatment. ${ }^{10}$

Furthermore, our case suggests that hypersensitivity to NSAIDs is not exclusively mediated by COX-1 blockade, but can also be provoked by selective COX-2 inhibitors that can function as haptens, resulting in anaphylaxis upon next exposure. $^{5}$ Our case shows that these reactions are not mediated by TNF $\alpha$ and not altered by TNF $\alpha$ neutralisation.

\section{Authors' affiliations}

E H J G Aarntzen, P L C M van Riel, P Barrera, Department of Rheumatology, Radboud University Nijmegen Medical Centre, PO Box 9101, 6500 HB Nijmegen, The Netherlands

Competing interests: none

Correspondence to: Dr P Barrera, p.barrera@reuma.umcn.nl

Accepted 24 June 2005

Published Online First 13 July 2005

\section{REFERENCES}

1 Husni ME, Maier AL, Mease PJ, Overman SS, Fraser P, Gravallese EM, et al. Etanercept in the treatment of adult patients with Still's disease. Arthritis Rheum 2002;46:1171-6.

2 Fautrel B, Sibilia J, Mariette X, Combe B. Tumour necrosis factor alpha blocking agents in refractory adult Still's disease: an observational study of 20 cases. Ann Rheum Dis 2005;64:262-6.

3 Vasques Godinho FM, Parreira Santos MJ, Canas da Silva J. Refractory adult onset Still's disease successfully treated with anakinra. Ann Rheum Dis 2005;64:647-8.

4 West PM, Fernandez C. Safety of COX-2 inhibitors in asthma patients with aspirin hypersensitivity. Ann Pharmacother 2003;37:1497-501.

5 Stevenson DD, Simon RA. Lack of cross-reactivity between rofecoxib and aspirin in aspirin-sensitive patients with asthma. J Allergy Clin Immunol 2001; 108:47-51.

6 Berkes EA. Anaphylactic and anaphylactoid reactions to aspirin and other NSAIDs. Clin Rev Allergy Immunol 2003;24:137-48.

7 Quartier $P$, Taupin $P$, Bourdeaut $F$, Lemelle I, Pillet $P$, Bost $M$, et al. Efficacy of etanercept for the treatment of juvenile idiopathic arthritis according to the onset type. Arthritis Rheum 2003;48:1093-101.

8 Horneff G, Schmeling H, Biedermann T, Foeldvari I, Ganser G, Girschick HJ, et al. The German etanercept registry for treatment of juvenile idiopathic arthritis. Ann Rheum Dis 2004:63:1638-44.

9 Pascual V, Allantaz F, Arce E, Punaro M, Banchereau J. Role of interleukin-1 (IL-1) in the pathogenesis of systemic onset juvenile idiopathic arthritis and clinical response to IL-1 blockade. J Exp Med 2005;201:1479-86.

10 Dinarello CA. Blocking IL-1 in systemic inflammation. J Exp Med 2005;201:1355-9.

\section{Distal degeneration of sensory and autonomic cutaneous nerve fibres in systemic sclerosis}

\section{Provitera, M Nolano, N Pappone, C di Girolamo, A Stancanelli, F Lullo, C Crisci, L Santoro}

W studied innervation and dermal vasculature in affected and apparently normal skin of sclerodermic patients to evaluate the involvement of different nerve fibre groups and to determine a possible correlation with vascular damage in this disease. Immunohistochemical analysis and confocal microscopic examination of skin biopsy samples were used.

\section{METHODS AND RESULTS}

We obtained $3 \mathrm{~mm}$ punch skin biopsy samples from the distal thigh and distal leg in 11 consecutive 34-70 year old female patients with systemic sclerosis (SSc), identified by the American College of Rheumatology classification criteria. ${ }^{1}$ We excluded patients who had been exposed to potentially neurotoxic exogenous or endogenous conditions. The skin appeared sclerotic in 4/11 patients in the leg and in 3/11 in the thigh (table 1). In four patients a further skin sample from fingertip was taken to evaluate myelinated fibres. None of the patients complained of sensory disturbances, and neurological and neurophysiological evaluations were normal except in two patients, in whom a conduction velocity study showed the presence of an entrapment syndrome. Patient morphological findings were compared with data from a group of 16 healthy volunteers (nine male, seven female, age range 34-65 years).

Skin biopsy specimens were processed according to previously published procedures. ${ }^{2}$ Floating sections were immunostained using a panel of primary antibodies, including the pan-neuronal marker anti-protein gene product (PGP) 9.5, anti-myelin basic protein for myelinated fibres, anti-vasoactive intestinal peptide (VIP) to mark autonomic nerve fibres, and anti-collagen IV to visualise basement membrane and blood vessels.

We quantified, as previously described, epidermal nerve fibres (ENFs) per linear millimetre, ${ }^{3}$ Meissner corpuscles (MCs), and myelinated papillary endings per square millimetre $^{4}$ on confocal images using image analysis software (Neurolucida, Microbrightfield Inc, Colchester VT, USA; ScionImage, Scion Corporation, Frederick, MD, USA). On the same images used to quantify ENF density, we measured blood vessel density in $\mu \mathrm{m}^{2} / 100 \mu \mathrm{m}^{2}$ of dermal tissue within $250 \mu \mathrm{m}$ below the basement membrane.

We found a significant loss of ENFs in sclerodermic patients in all the examined sites (table 1) without a distalproximal gradient, a poor subepidermal neural plexus, and a reduced innervation of sweat glands, blood vessels, and arrector pilorum muscles compared with controls. These findings, evident in apparently unaffected areas (figs $\mathrm{IE}$ and F compared with $1 \mathrm{~A}$ and $\mathrm{B}$ ), were more severe in clinically involved skin (figs $1 \mathrm{C}$ and D compared with $\mathrm{IA}$ and B) and affected both sensory and autonomic unmyelinated nerve fibres as demonstrated by PGP and VIP immunostainings.

The mean (SD) density of blood vessels measured in $\mu \mathrm{m}^{2}$ / $100 \mu \mathrm{m}^{2}$ of dermal tissue, was 6.4 (2.9) and 8.7 (4.7), respectively, in the thigh and leg of patients with SSc. These values significantly correlated with the density of epidermal nerve fibres in both sites $\left(r^{2}=0.51 ; \mathrm{p}<0.05\right.$ at the thigh and $r^{2}=0.58 ; \mathrm{p}<0.05$ at the leg). In glabrous skin we found a significant reduction of MC density compared with controls, with a number of intrapapillary myelinated fibres still within the normal range. Moreover, evident structural abnormalities of the surviving mechanoreceptors and predegenerative 


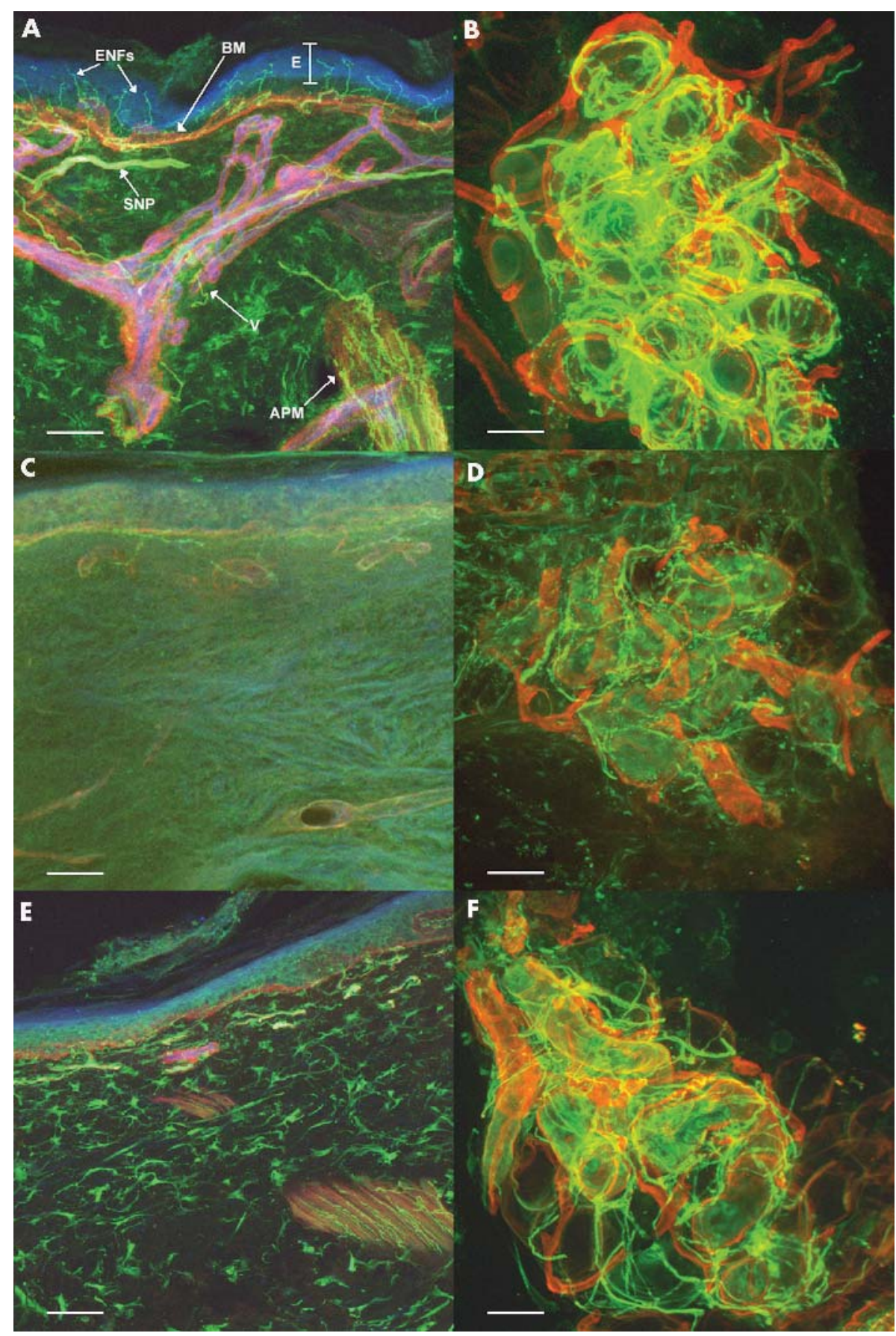

Figure 1 Confocal micrographs of cutaneous innervation in thigh skin samples. (A) Normal skin, (C) affected, and (E) apparently unaffected skin from a patient with SSc: samples are triple stained to visualise nerve fibres (rPGP in yellow-green), basement membrane and vessels (mCollV in red), and endothelium and epidermis (ULEX Europaeus in blue). Sweat gland images in a healthy subject (B) and in sclerodermic patients from affected (D) and apparently normal (F) skin, are double stained to visualise nerve fibres (rPGP in yellow-green) and vessels ( $\mathrm{mCollV}$ in red). A derangement of dermal architecture, of subepidermal neural plexus, and a marked reduction of ENF density are evident in affected and, although to a lesser extent, in apparently normal skin of patients with SSc (C and E compared with A). A loss of nerve fibres innervating dermal annexes such as arrector pilorum muscles ( $E$ compared with $A$ ) and sweat glands ( $D$ and $F$ compared with $B$ ) in skin from sclerodermic patients is also evident. Bar $=50 \mu \mathrm{m}$. $E$, epidermis; ENFs, epidermal nerve fibres; BM, basement membrane; V, blood vessels; SNP, subepidermal neural plexus; APM, arrector pilorum muscle.

aspects of myelinated fibres, such as swellings or vacuolisation, were present.

\section{DISCUSSION}

Our data indicate that the cutaneous nerves in SSc are impaired. This mainly involves the unmyelinated sensory and autonomic nerve fibres, but does not completely spare the large fibres. The observation that the loss of ENFs was more significant in subjects with an evident reduction of vascular bed suggests that ischaemia may have a role in determining the neuropathic process. However, we cannot rule out the possibility that early biohumoral changes, demonstrated in apparently unaffected skin, ${ }^{5}$ may induce both neural and vascular damage. We speculate that the abnormalities of terminal innervation seen in the skin may be present in multiple organs in SSc. This neuropathic process, affecting 
Table 1 Clinical and morphological data in sclerodermic patients compared with mean values in the control group

\begin{tabular}{|c|c|c|c|c|c|c|c|c|c|c|}
\hline Patient & Age & $\begin{array}{l}\text { Disease } \\
\text { duration } \\
\text { (years) }\end{array}$ & Subset & ENF thigh* & $\begin{array}{l}\text { Dermal } \\
\text { vessels } \\
\text { density } \\
\text { thight }\end{array}$ & ENF leg* & $\begin{array}{l}\text { Dermal } \\
\text { vessels } \\
\text { density } \\
\text { legt }\end{array}$ & $\begin{array}{l}\text { ENF } \\
\text { fingertip* }\end{array}$ & $\begin{array}{l}\text { Meissner } \\
\text { corpusclesł }\end{array}$ & $\begin{array}{l}\text { Myelinated } \\
\text { intrapapillary } \\
\text { endings }\end{array}$ \\
\hline 1 & 62 & 1 & ISSc & 15.8 & 8.1 & 10.3 & 8.7 & 7.4 & 20.5 & 42.7 \\
\hline 2 & 43 & 13 & dSSc & 7.3 & 7.8 & 9.0 & 7.1 & - & - & - \\
\hline 3 & 63 & 1 & ISSc & 6.0 & 2.2 & 3.5 & 11.3 & 1.9 & 8.6 & 18.3 \\
\hline 4 & 62 & 2 & ISSc & 16.6 & 9.6 & 9.3 & 9.2 & - & - & - \\
\hline 5 & 34 & 6 & dSSc & $(0.0)$ & 4.7 & (0.0) & 1.5 & - & - & - \\
\hline 6 & 65 & 5 & $\mathrm{dSSc}$ & 2.0 & 11.8 & $(0.0)$ & 3.4 & - & - & - \\
\hline 7 & 46 & 2 & $\mathrm{dSSc}$ & $(0.0)$ & 3.0 & (3.1) & 2.8 & - & - & - \\
\hline 8 & 41 & 1 & ISSc & 18.7 & 8.0 & 10.5 & 12.0 & - & - & - \\
\hline 9 & 60 & 8 & $\mathrm{dSSc}$ & $(0.0)$ & 7.1 & $(0.0)$ & 9.6 & - & - & - \\
\hline 10 & 70 & 3 & ISSc & 20.5 & 8.3 & 23.8 & 16.2 & 3.5 & 15.1 & 63.9 \\
\hline 11 & 70 & 5 & ISSc & 13.3 & 9.7 & 11.5 & 13.6 & 2.2 & 15.0 & 37.2 \\
\hline \multicolumn{11}{|l|}{ Mean (SD) } \\
\hline Patients & $56.0(12.6)$ & 4.3 (3.7) & & 9.1 (8.1) & $6.4(2.9)$ & $7.4(7.1)$ & 8.7 (4.7) & $3.8(2.5)$ & $14.8(4.9)$ & 40.5 (18.8) \\
\hline Controls & $52.6(10.0)$ & - & & $27.2(7.7)$ & - & $19.1(8.8)$ & - & $7.5(3.6)$ & $29.7(11.2)$ & $51.9(20.7)$ \\
\hline Significance & & & & $\begin{array}{l}p<0.0001 \S \\
p<0.005\end{array}$ & & $\begin{array}{l}p<0.001 \S \\
p<0.05^{*}\end{array}$ & & $\mathrm{p}<0.05 \S$ & $p<0.005 \S$ & $p=0.34 \S$ \\
\hline
\end{tabular}

ENF density values from affected skin are shown in parentheses.

ISSc, limited cutaneous systemic sclerosis; dSSc, diffuse cutaneous systemic sclerosis.

*Expressed as the number of epidermal nerve fibres $/ \mathrm{mm}$; †expressed in $\mu \mathrm{m}^{2} / 100 \mu \mathrm{m}^{2}$ of dermal tissue; $\ddagger$ expressed as the number of structures/mm ; §comparison of density values in the control group and in all skin samples from patients with SSc; 9 comparison of density values in the control group and in samples of apparently unaffected skin in patients with SSc.

primarily unmyelinated nerve fibres, may contribute to the production of abnormalities that are common in SSc, like visceral dysmotility and cardiac arrhythmias.

\section{Authors' affiliations}

V Provitera, M Nolano, A Stancanelli, F Lullo, Neurology Division, "Salvatore Maugeri" Foundation, IRCCS, Centre of Telese Terme, Italy N Pappone, Rheumatology Division, "Salvatore Maugeri" Foundation, IRCCS, Centre of Telese Terme, Italy

C di Girolamo, Rheumatology Unit, "G Rummo" Hospital, Benevento, Italy C Crisci, Clinic Centre, Private Hospital for Rehabilitation, Naples, Italy

L Santoro, Department of Neurological Sciences, University of Naples

"Federico II", Italy

Competing interest statement: No author has any competing interest regarding this report.

Correspondence to: Dr V Provitera, Neurology Division, "Salvatore Maugeri" Foundation, IRCCS, Via Bagni Vecchi 1, 82037, Telese Terme (BN), Italy; vprovitera@fsm.it
Accepted 30 March 2005

\section{REFERENCES}

1 ARA. Subcommittee for Scleroderma Criteria of the American Rheumatism Association Diagnostic and Therapeutic Criteria Committee. Preliminary criteria for the classification of systemic sclerosis (scleroderma). Arthritis Rheum 1980;23:581-90.

2 Kennedy WR, Wendelschafer-Crabb G. The innervation of human epidermis. J Neurol Sci 1993; 115:184-90.

3 Kennedy WR, Wendelschafer-Crabb G, Johnson T. Quantitation of epidermal nerves in diabetic neuropathy. Neurology 1996;47:1042-8.

4 Nolano M, Provitera V, Crisci C, Stancanelli A, Wendelschafer-Crabb G, Kennedy WR, et al. Quantification of myelinated endings and mechanoreceptors in human digital skin. Ann Neurol 2003;54:197-205.

5 Søndergaard K, Stengaard-Pedersen K, Zachariae H, Heickendorff L, Deleuran M, Deleuran B. Soluble intercellular adhesion molecule-1 (sICAM-1) and soluble interleukin-2 receptors (sIL-2R) in scleroderma skin. Br J Rheumatol 1998;37:304-10.

6 Claman HN, Giorno RC, Seibold JR. Endothelial and fibroblastic activation in scleroderma. The myth of the "uninvolved skin". Arthritis Rheum 1991;34:1495-501. 